\title{
Notes on the authors
}

David Arculus has been Chairman of the Better Regulation Task Force since 2002. He is also Chairman of O2, a non-executive director of Barclays plc, a delegate of the Finance Committee at Oxford University Press, a member of the Council of the Confederation of British Industry and an advisory board member, Veronis Suhler Stevenson International Limited.

Chris Bolt was appointed by the Secretary of State for Transport as the statutory arbiter for the London Underground PPP Agreements from 31 December 2002 for four years. He was appointed as the Chairman of the Office of Rail Regulation from 5 July 2004, for a five-year term.

An economist by training, his career has included senior roles in both the public and private sector. From 1988 to 1989 , he was part of the DoE team responsible for privatizing the water industry and establishing its initial regulatory regime. He then joined Ofwat, on its establishment, as Head of Economic Regulation. He moved to ORR in a similar role in 1994 and was appointed as Rail Regulator in December 1998.

In July 1999, he joined Transco plc, and became Regulation and Corporate Affairs Director. He was appointed to a new role of Group Director, Regulation and Public Policy in Transco's parent company, Lattice Group plc, in November 2001. He left Lattice in October 2002 on completion of its merger with National Grid Group plc.

Robert W. Crandall is a Senior Fellow in the Economic Studies Program of the Brookings Institution. His research has focused on telecommunications regulation, cable television regulation, the effects of trade policy in the steel and automobile industries, environmental policy, and the changing regional structure of the US economy. His current research focuses on competition in the telecommunications sector and the development of broadband services. His book on universal service, Who Pays for 'Universal Service'? (written with Leonard Waverman of the London Business School), was published by Brookings in 2000. He was also a contributor, with Professor Jerry Hausman of MIT, to the recently published Brookings book, Deregulation of Network Industries: What's Next? (edited by Sam Peltzman and Clifford Winston). 
Crandall was a Johnson Research Fellow at the Brookings Institution and has taught economics at Northwestern University, MIT, the University of Maryland, the George Washington University, and the Stanford in Washington program. Before assuming his current position at Brookings, he served as assistant, acting, and deputy director for the Council on Wage and Price Stability.

Crandall is the author of Talk is Cheap: The Promise of Regulatory Reform in North American Telecommunications (with Leonard Waverman) (Brookings Institution, 1996); Cable TV: Regulation or Competition? (with Harold Furchtgott-Roth) (Brookings Institution, 1996); The Extra Mile: Rethinking Energy Policy for Automotive Transportation (with Pietro Nivola) (Brookings Institution, 1995); After the Breakup: The U.S. Telecommunications Sector in a More Competitive Era; Manufacturing on the Move; Changing the Rules: Technological Change. International Competition, and Regulation in Communications (with Kenneth Flamm) (Brookings Institution, 1991), and numerous journal articles.

He holds an MS and a Ph.D. in economics from Northwestern University.

Philip Fletcher was appointed for a renewable five-year term as Director General of Water Services on 1 August 2000.

His previous career was based mainly in central government public service, with an emphasis on financial issues.

Born in 1946, Philip's immediate previous post was as Receiver for the Metropolitan Police District from 1996. The Receiver had statutory responsibility for the administration of the Metropolitan Police Fund. He was a full member of the Commissioner's management team but was separately accountable to the Home Secretary. He was in charge of finance, procurement, internal audit and property services, and the legal owner of all Metropolitan Police property. In that role, he managed projects to improve financial management and review and outsource support services.

Earlier, he was a founder member of the Department of the Environment from 1970. His work there covered such issues as planning and land use, urban regeneration, rural issues, local government, finance and private housing. As Director of Central Finance there, he took part in the issues leading up to the privatization of the water industry in England and Wales in 1989.

Fletcher was appointed Chief Executive of PSA Services (the former Property Services Agency) in 1993. When he had completed its privatization, he transferred to head the Cities and Countryside Group in DoE in 1994. 
Educated at Marlborough College and Oxford University, Philip Fletcher is married with one daughter. He is a lay reader in the Church of England and his hobbies include walking and bird-watching.

Annegret Groebel was born in 1960 in Hanau (Main), Germany. From 1981 to 1986 she was a student at the University of Heidelberg (MA in economics) and at the University Paris IX (Dauphine), France. Her Ph.D. in economics was at the University of Mannheim. She joined the BMPT (Federal Ministry of Posts and Telecommunications) in 1997 as a junior representative in the Special Network Access incl. Interconnection section. From 1998 to 2001 she was Vice-Chair of Ruling Chamber 4 - Special Network Access incl. Interconnection of the Regulatory Authority for Telecommunications and Posts (RegTP). She was Research Fellow at the Global Communications Consortium (Director: Prof. Len Waverman) of London Business School from October to December 2000. Since May 2001 she has been Head of the Co-ordination of RegTP's International Activities/Bodies section and since July 2002 she has been a member of the IRG Secretariat and Chair of the IRG Fixed-Network Working Group.

Frédéric Jenny is a Professor in the Economics Department and Director of International Relations at ESSEC. He has doctorates from Université de Paris II and Harvard. Since 1994 he has been Chairman of the Committee on Competition Law and Policy of the Organization for Economic Co-operation and Development; he is a Judge on the French Supreme Court and the former Vice Chairman of the Competition Council; and he chaired the World Trade Organization's Task Force on the Interaction between Commerce and Competition Policy until 2003. His principal research interests are in the relationship between structure and performance in France and other European countries and in European antitrust legislation. He has published numerous books and papers on microeconomic theory, competition policy, mergers and regulation.

Stephen Littlechild was UK Director General of Electricity Supply (DGES) for nearly ten years. He was in charge of the Office of Electricity Regulation (Offer), from its foundation in September 1989, to December 1998. Previously he advised ministers on the regulatory regime for British Telecom and the water industry. In 1983, he proposed the RPI-X approach to price controls, which has since been widely adopted for regulating utilities in the UK and overseas. He was a member of the Monopolies and Mergers Commission for six years. Before 1989, he acted as a consultant to public and private sector organizations including HM Treasury, several UK government departments. 
NZ Treasury, the World Bank, AT \& T, Bell Telephone Laboratories and General Motors.

Professor Littlechild graduated as Bachelor of Commerce from the University of Birmingham in 1964. He did postgraduate work at Stanford University (Operations Research program) 1965-67, Northwestern University (Engineering faculty) 1967-68, and the University of Texas at Austin (Graduate School of Business) 1968-69, obtaining his Ph.D. there in 1969. He did postdoctoral research at UCLA and Northwestern. From 1972 to 1975 he was Professor of Applied Economics and Head of the Economics, Econometrics, Statistics and Marketing Subject Group at Aston Management Centre. He was Professor of Commerce and Head of the Department of Industrial Economics and Business Studies at the University of Birmingham from 1975 to 1989. During 1979-80 he was a visiting professor or research fellow at Stanford University, New York University, University of Chicago and Virginia Polytechnic and Institute. Since 1994, he has been an honorary professor in the University of Birmingham Business School.

Professor Littlechild's publications include Operational Research for Managers (Philip Allan, 1976), The Fallacy of the Mixed Economy (1EA, 1978), Elements of Telecommunications Economics (Institute of Electrical Engineers, 1979), Energy Strategies for the UK (with K.G. Vaidya) (Allen and Unwin, 1982), Regulation of British Telecommunications' Profitability (Department of Industry, 1983), Economic Regulation of Privatized Water Authorities (HMSO, 1986), and over 60 articles.

Since stepping down as DGES at the end of 1998, Professor Littlechild has engaged in lecturing and consulting for government departments, regulatory bodies, universities, research institutes, regulated companies and international organizations including the World Bank. He has been involved since January 1999 in policy discussions in the USA, Mexico, India, Brazil, Australia, New Zealand, Poland, Thailand, the Philippines, Spain, Germany, Argentina and Italy, as well as in the UK. In May 1999, Stanford University conferred on him the Zale Award for Scholarship and Public Service. He was awarded an Honorary D.Sc. by the University of Birmingham in 2001.

Eileen Marshall worked as a stockbroker in the City of London before becoming a university lecturer, then senior lecturer, in industrial economics. Her research specialism was in energy economics and she acted as consultant to many companies and bodies.

Dr Marshall took up the position of Director of Regulation and Business Affairs with the Office of Electricity Regulation (Offer) in October 1989. In April 1994, she was appointed Chief Economic Adviser and Director 
of Regulation and Business Affairs at the Office of Gas Supply (Ofgas). Her responsibilities covered the full range of Ofgas policy issues, including the setting of price controls and the introduction of domestic competition. In January 1997, while retaining her previous responsibilities at Ofgas, Dr Marshall became a part-time economic adviser to Offer, and from autumn 1997 led the Review of Electricity Trading Arrangements. In January 1998, she was awarded the CBE for services to regulatory policy. In June 1999, the former regulatory offices, Ofgas and Offer, were merged and renamed the Office of Gas and Electricity Markets (Ofgem). Dr Marshall took up the new position of Deputy Director General, with particular responsibility for competition and trading arrangements.

Colin Mayer is Peter Moores Professor of Management Studies at the Saïd Business School, University of Oxford, Professorial Fellow at Wadham College, Oxford and Director of the Oxford Financial Research Centre. He was a Harkness Fellow at Harvard University (1979/80), a HoublonNorman Fellow at the Bank of England (1989) and the first Leo Goldschmidt Visiting Professor in Corporate Governance at the Solvay Business School, Université Libre de Bruxelles (2000 and 2001). He is a member of the Executive Committee of the Royal Economic Society, and an Inaugural Fellow and Board Member of the European Corporate Governance Institute (ECGI) in Brussels. He is a director of OXERA Holdings Ltd, a delegate and Chairman of the Audit Committee of the Oxford University Press, an Honorary Fellow of St Anne's College, Oxford, a governor of St Paul's School, London and is on the editorial board of numerous economics and finance journals.

He researches in the fields of corporate finance, governance, regulation and taxation. He has worked on international comparisons of financial systems and corporate governance and their effects on the financing and control of corporations. He also researches financial aspects of the regulation of utilities and the regulation of financial institutions.

Recent publications include 'Financing the New Economy: Financial Institutions and Corporate Governance', Information Economics and Policy, 2002, Asset Management and Investor Protection, with Julian Franks and Luis Correia da Silva, Oxford University Press, 2002, and 'Finance, Investment and Growth', with Wendy Carlin, Journal of Financial Economics, 2003.

Sir Derek Morris is Provost of Oriel College, Oxford. He was previously Chairman of the Competition Commission (formerly the Monopolies and Mergers Commission). He first joined the MMC in 1991 as a member, becoming a deputy chairman in 1995 and chairman in 1998. Having studied Politics, Philosophy and Economics at Oxford from 1964 to 1967 , and 
then for a D.Phil. in economics at Nuffield College, he took up a Research Fellowship at the Centre for Business and Industrial Studies at Warwick University. Then, from 1970 until 1998, he was fellow and tutor in economics at Oriel College, Oxford.

During this time he wrote numerous books and articles, primarily in the field of industrial economics. Books included The Economic System in the UK (third edition, Oxford University Press, 1985); Unquoted Companies (Macmillan, 1984); Industrial Economics and Organisation (Oxford University Press, 1979, second edition, 1991); and Chinese State Owned Enterprises and Economic Reform (the last three co-written by D. Hay). Other academic activities included chairmanship of the Economics sub-faculty and then Social Studies faculty at Oxford and editorial board responsibilities for the Journal of Industrial Economics, the Oxford Review of Economic Policy, Oxford Economic Papers, among others.

Other activities have included three years on secondment as Economic Director of the National Economic Development Council, and Chairman of Oxford Economic and Social Research. He has also been involved for over 20 years in various types of advisory and consultancy work, initially in the field of competition policy but more recently for the Asian Development Bank, in helping to design and implement economic reform measures in China and Central Asia.

Derek Morris was knighted in the 2002 New Year Honours List.

Jrissy Motis is a Ph.D. student at the Universite des Sciences Sociales de Toulouse.

Damien Neven is Professor of International Economics at the Graduate Institute of International Studies, Geneva. Previous appointments include Professeur Ordinaire, Universite de Lausanne, Professor, Universite de Liege and Associate Professor of Economics, INSEAD. His principal research interests are in industrial organization and international integration. Current research is focussed on the co-ordination of antitrust policies across jurisdictions, merger control and the antitrust analysis of sports competitions. He has been a member of the Economic Advisory Committee to the Directorate General for Competition of the EU since 1996.

Sir Charles Nicholson has, in a 35-year career with BP plc, held a variety of posts. In 1975 he became involved with the development of BP's position in the USA and in 1979 moved to New York as Vice-President of Government and Public Affairs. He was later appointed Head of Corporate Communications in London and currently holds the position of Group Senior Advisor. He has been closely involved with the development of BP's 
position on the environment and sustainable development. He chairs the Climate \& Energy Groups of the World Business Council for Sustainable Development and the European Round Table.

$\mathrm{He}$ is a graduate of Oxford University and the Sloan Fellowship Programme.

Sir Geoffrey Owen is senior fellow at the Inter-Disciplinary Institute for Management, London School of Economics, where he specializes in issues relating to corporate strategy, corporate performance and industry evolution. Before joining the LSE in 1991, Sir Geoffrey spent most of his earlier career as a journalist on the Financial Times, where he held several posts, including US Correspondent and Industrial Editor, before being appointed Editor in 1980. He served as Editor for ten years. Between 1967 and 1972 he worked first as an executive in the Industrial Reorganisation Corporation and then in the international division of British Leyland Motor Corporation. His most recent book is From Empire to Europe: the decline and revival of British industry since the second world war (HarperCollins, 1999).

Colin Robinson was educated at the University of Manchester, and then worked for 11 years as a business economist before being appointed, in 1968, to the Chair of Economics at the University of Surrey where he founded the Department of Economics and is now Emeritus Professor.

He is a Fellow of the Royal Statistical Society, Fellow of the Society of Business Economists and Fellow of the Institute of Energy. He is a past member of the Monopolies and Mergers Commission and of the Secretary of State for Energy's Advisory Council on Research and Development (ACORD). He was named British Institute of Energy Economics 'Energy Economist of the Year' in 1992 and in 1998 received the award of 'Outstanding Contribution to the Profession and its Literature' from the International Association of Energy Economics.

Robinson is sole or joint author of 23 books and monographs and over 150 papers, including studies of North Sea oil and gas, the British coal industry, energy policy, nuclear power, energy privatization programmes and the international oil, gas and coal markets. He has appeared as expert witness in numerous legal proceedings in Britain and abroad.

He was Editorial Director of the Institute of Economic Affairs from 1992 to 2002 and is a member of the Institute's Academic Advisory Council and a Trustee of the Wincott Foundation.

Paul Seabright is Professor of Economics at the Universite des Sciences Sociales de Toulouse, having previously been Reader in Economics at the University of Cambridge, 1999-2001, Lecturer in Economiçs at the College 
of Europe, Bruges, 1998-99 and Assistant Director of Research, University of Cambridge, 1988-99. His main research interests are in microeconomic theory, industrial and competition policy, development economics, industrial policy in transition economies, state aids to industry, economic geography and European integration. He is Managing Editor, Economic Policy, a member of the European Commission's Academic Advisory Panel on Competition Policy Questions, and a Commissioner on the Independent Commission on UK membership of the euro appointed by the Britain in Europe group.

Jacques Steenbergen is a partner in the European Union practice group in Brussels. He practises competition and European law. He teaches competition law at the University of Louvain (KUL), has been a regular visiting professor at the University of Amsterdam and is chairman of the Board of Editors of the Belgian-Dutch law review $S E W$. He is an active member of various professional and scientific organizations. He has published extensively on European Community and economic law and lectures at seminars and universities in Europe, the USA and China. Jacques Steenbergen received his first degrees in law, philosophy and economics from the University of Antwerp (UFSIA), and his Master's and Doctoral degrees in law from the University of Louvain (KUL).

Sir John Vickers became Director General of Fair Trading on 1 October 2000 and OFT Chairman on 1 April 2003. Previously he spent two and a half years as Chief Economist at the Bank of England, and was a member of the Monetary Policy Committee. Most of his career has been spent teaching economics at Oxford University, where he was made the Drummond Professor of Political Economy in 1991. He has published widely on privatization, regulation and competition. He is a fellow of the British Academy, the Econometric Society and All Souls College, Oxford. He was knighted in 2005.

Leonard Waverman is Professor and Chair of Economics as well as Director of the Centre for the Network Economy at the London Business School. He has recently been appointed Director of the Economic and Social Research Council's E-Society Research Programme and has been awarded a four-year $£ 1.1$ million research grant from the Leverhulme Trust to examine 'the social/economic impact of information and communication technology' - why don't we see the 'New Economy' in Europe?

He received his B.Comm. and MA from the University of Toronto, and his Ph.D. from MIT. His teaching specialities are in telecommunications, antitrust and energy economics. A recent paper is 'Telecommunications 
Infrastructure and Economic Development: A Simultaneous Approach' with H. Roeller, American Economic Review, September 2001.

Professor Waverman is a non-executive board member of GEMA - the UK's electricity and gas market authority. He is a member of the Scientific Advisory Board of the German Institute for Economic Research in Berlin (DIW). He is a Fellow of Columbia University's Centre for TeleInformation. He was on the Advisory Committee introducing Competition in Ontario's Electricity system (1995-96), a part-time board member of the Ontario Energy Board, as well as of the Ontario Telephone Service Commission, and a member of the National Association of Regulatory Utility Commissioners (NARUC) for six years.

Professor Waverman advises several European governments on competition, communications and innovation policies. He has consulted extensively in North America, Europe and Australia and has appeared before regulatory authorities, competition tribunals, agencies and courts. Recently, he represented Schneider Electric at the European Commission and at the Court of First Instance in Luxemburg in their attempt to purchase Legrand.

Professor Waverman has received the honour of Chevalier dans l'Ordre des Palmes Academiques of the government of France.

Tom Winsor was appointed Rail Regulator and International Rail Regulator for five years with effect from 5 July 1999.

He was born in 1957 and brought up in Broughty Ferry, Dundee. He was educated at Grove Academy, Broughty Ferry and then at the University of Edinburgh, where he graduated with an LL.B. (Scots Law) in 1979. As a solicitor, he qualified first in Scotland, where he is a Writer to the Signet, and subsequently in England and Wales. After general practice in Dundee, he took a postgraduate qualification in oil and gas law at the Centre for Energy, Petroleum and Mineral Law and Policy of the University of Dundee.

In the course of his legal career, Tom Winsor specialized first in UK and international oil and gas law, later adding electricity, regulation, railways and public law. He joined Denton Hall as a partner in 1991, where he was responsible for the design of the regulatory regime for the electricity industry in Northern Ireland. In 1993 he was seconded to the Office of the Rail Regulator as Chief Legal Adviser and later as General Counsel. He returned to his partnership at Denton Hall in 1995 as head of the railways department, part of the firm's energy and infrastructure practice.

Tom Winsor is an honorary lecturer at the Centre for Energy, Petroleum and Mineral Law and Policy of the University of Dundee, where he directed the UK Oil and Gas Law summer course from 1993 to 1997. He is married, 
with one daughter, and lives in Kent, travelling daily to his office in London by train.

Clifford Winston, a Senior Fellow in the Economic Studies programme, has been with the Brookings Institution since 1984. He specializes in analysis of industrial organization, regulation and transportation.

Winston has also been co-editor of the annual microeconomic edition of Brookings Papers on Economic Activity. Before his fellowship at Brookings, he was Associate Professor at the Transportation Systems Division of Massachusetts Institute of Technology's Department of Civil Engineering.

The author of numerous books and articles, Winston has published Deregulation of Network Industries: What's Next?, with Sam Peltzman (AEI-Brookings, 2000); Essays in Transportation Economics and Policy: A Handbook in Honor of John R. Meyer, with Jose A. Gomez-Ibanez and William B. Tye (1999); Alternate Route: Toward Efficient Urban Transportation, with Chad Shirley (1998); The Evolution of the Airline Industry, with Steven A. Morrison (1995); The Economic Effects of Surface Freight Deregulation, with Thomas M. Corsi, Curtis M. Grimm and Carol A. Evans (1990); Road Work: A New Highway Pricing and Investment Policy, with Kenneth A. Small and Carol Evans (1989); Liability: Perspectives and Policy, with Robert E. Litan (1988); Blind Intersection? Policy and the Automobile Industry, co-author (1987); and The Economic Effects of Airline Deregulation, with Steven Morrison (1986). His articles have appeared in such journals as American Economic Review, Econometrica, Review of Economics and Statistics, Journal of Economic Literature, Bell Journal of Economics and the Rand Journal of Economics.

Dr Winston received his A.B. in economics from the University of California at Berkeley in 1974, his M.Sc. from the London School of Economics in 1975, and his Ph.D. in economics from U.C. Berkeley in 1979. 
Colin Robinson - 9781845426835 Downloaded from PubFactory at $04 / 26 / 2023$ 12:28: ๑9PM 